\title{
Potentiation of the bronchoprotective effects of vasoactive intestinal peptide, isoprenaline, and theophylline against histamine challenge in anaesthetised guinea pigs by adrenomedullin
}

\author{
H Kanazawa, T Kawaguchi, T Fujii, S Shoji, K Hirata, S Kudoh, N Kurihara, \\ J Yoshikawa
}

\begin{abstract}
Background - Adrenomedullin is a hypotensive peptide recently discovered in human phaeochromocytoma which has been found to inhibit bronchoconstriction induced by histamine and acetylcholine. This study was designed to determine the manner in which adrenomedullin and other bronchodilators interact in modulating airway function.

Methods - A study was undertaken to determine whether adrenomedullin potentiated the bronchoprotective effects of isoprenaline, vasoactive intestinal peptide (VIP), and theophylline against histamine-induced bronchoconstriction in anaesthetised guinea pigs in vivo.
\end{abstract}

Results - Adrenomedullin in a concentration of $10^{-9} \mathrm{M}$ significantly inhibited histamine-induced bronchoconstriction but in a concentration of $10^{-10} \mathrm{M}$ it did not exhibit the bronchoprotective effect against histamine. VIP $\left(10^{-9} \mathrm{M}\right)$ did not affect histamine-induced bronchoconstriction but it markedly inhibited the bronchoprotective effect against histamine in the presence of adrenomedullin $\left(10^{-10} \mathrm{M}\right)$. VIP $\left(10^{-6} \mathrm{M}\right)$ significantly inhibited histamine-induced bronchoconstriction but this effect was short lived. Adrenomedullin in a concentration of $10^{-10} \mathrm{M}$ potentiated bronchoprotection induced by VIP $\left(10^{-6} M\right)$ and prolonged it. Isoprenaline $\left(10^{-8} \mathrm{M}\right)$ also significantly inhibited histamine-induced bronchoconstriction and this effect was enhanced in the presence of adrenomedullin $\left(10^{-10} \mathrm{M}\right)$. Similarly, adrenomedullin $\left(10^{-10} \mathrm{M}\right)$ significantly potentiated theophylline-induced bronchoprotection, and a sub-bronchoprotective dose of theophylline $(20 \mathrm{mg} / \mathrm{kg}$ i.p.) was effective in preventing histamine-induced bronchoconstriction in the presence of adrenomedullin $\left(10^{-10} \mathrm{M}\right)$.

Conclusions - This study shows that adrenomedullin potentiates the bronchoprotective effects of different classes of bronchodilators against histamine challenge in anaesthetised guinea pigs.

(Thorax 1996;51:1199-1202)

Keywords: adrenomedullin, bronchoprotection, cyclic AMP.
Adrenomedullin is a hypotensive peptide recently discovered in human phaeochromocytoma. The peptide, consisting of 52 amino acids, has one intramolecular disulphide bond and $17 \%$ amino acid sequence homology with calcitonin gene-related peptide. ${ }^{1} \mathrm{~A}$ cDNA clone encoding the porcine adrenomedullin precursor has been isolated and sequenced from rat and human tissue. With the use of RNA blot analysis, porcine adrenomedullin mRNA was shown to be highly expressed in lung tissue ${ }^{2}$ and adrenomedullin was synthesised by several cell populations of the lung including epithelium and airway smooth muscle cells. ${ }^{3}$ We have already shown that exogenous adrenomedullin induces long lasting bronchodilatation. ${ }^{4}$ Adrenergic agonists and theophylline are used clinically for treatment of bronchial asthma. They directly stimulate the production of cyclic adenosine monophosphate (cAMP) in airway smooth muscle cells, and theophylline prevents the degradation of cAMP to $5^{\prime}-\mathrm{AMP}$, thus increasing intracellular cAMP and causing relaxation. Vasoactive intestinal peptide (VIP), a 28 amino acid peptide, is the neuropeptide found in highest concentrations in human lung and is localised to efferent nerves. ${ }^{5}$ VIP immunoreactive nerve fibres are associated with airway smooth muscle, mucous glands, airway blood vessels, and parasympathetic ganglia. ${ }^{6}$ VIP is a potent relaxant of airway smooth muscle in vitro, and this relaxation is independent of adrenergic receptors. ${ }^{7}$ Torphy et al have already shown that phosphodiesterase inhibitors significantly potentiate isoprenaline-induced relaxation of human isolated bronchus. ${ }^{8}$ However, the manner in which adrenomodullin and these bronchodilators interact in modulating airway function has not yet been determined. In this study we have examined whether adrenomedullin potentiates the bronchoprotective effects of isoprenaline, VIP, and theophylline against histamine-induced bronchoconstriction in anaesthetised guinea pigs.

\section{Methods}

MEASUREMENT OF PULMONARY RESISTANCE Hartley male guinea pigs $(400-500 \mathrm{~g})$ were used in the study. They were anaesthetised with sodium pentobarbitone $(50 \mathrm{mg} / \mathrm{kg}$ intraperitoneally; Abbott Laboratories) and then ventilated artificially with a tracheal cannula 
using a constant volume ventilator (Model 680; Harvard Apparatus Co) at a frequency of 60 breaths $/ \mathrm{min}$. The tidal volume was set at $6 \mathrm{ml} /$ $\mathrm{kg}$. Airflow was monitored continuously using a pneumotachograph (TV-241T, Nihon Koden Co) connected to a differential pressure transducer (TP-602T, Nihon Koden Co). The tidal volume was determined by electrical integration of airflow. A fluid-filled polyethylene catheter was introduced into the oesophagus to measure oesophageal pressure as an approximation of pleural pressure. Intratracheal pressure was measured using a polyethylene catheter inserted into a short tube connecting the tracheal cannula to the pneumotachograph. The transpulmonary pressure (defined as the pressure difference between the intratracheal and oesophageal pressures) was measured with a differential pressure transducer. Pulmonary resistance was calculated as previously described. ${ }^{9}$ Aerosols of test agents (mass median aerodynamic diameter $1.8 \mu \mathrm{m}$; geometric standard deviation $2 \mu \mathrm{m}$; output $1.5 \mathrm{ml} / \mathrm{min}$ ) were generated with an ultrasonic nebuliser (TUR-3200, Nihon Koden Co) and delivered to the airways by the ventilator. The mean blood pressure and heart rate were monitored from the cannula in the right jugular artery with a Statham pressure transducer (model P231D; Gould, Saddle Brook, New Jersey, USA) connected to a polygraph (Polygraph System, Nihon Koden Co).

\section{EFFECT OF ADRENOMEDULLIN ON}

HISTAMINE-INDUCED BRONCHOCONSTRICTION

After measuring baseline $(100 \%)$ pulmonary resistance the guinea pigs were first exposed to adrenomedullin $\left(10^{-10} \mathrm{M}\right.$ or $10^{-9} \mathrm{M}, 30$ breaths at each concentration) and five minutes later to histamine $\left(10^{-3} \mathrm{M}, 20\right.$ breaths). The time of exposure to histamine was defined as time 0 .

\section{EFFECT OF ADRENOMEDULLIN ON THE BRONCHOPROTECTIVE EFFECTS OF VIP OR ISOPRENALINE}

The guinea pigs were first exposed to adrenomedullin $\left(10^{-10} \mathrm{M}, 30\right.$ breaths). Five minutes later they were exposed to VIP $\left(10^{-6} \mathrm{M}\right.$ or $10^{-9} \mathrm{M}, 30$ breaths at each concentration) or isoprenaline $\left(10^{-8} \mathrm{M}, 30\right.$ breaths) and then after a further five minutes they were exposed to histamine $\left(10^{-3} \mathrm{M}, 20\right.$ breaths $)$. The time of exposure to histamine was defined as time 0 . All data were standardised by the baseline pulmonary resistance and the percentage inhibitory effects of VIP and isoprenaline were calculated.

EFFECT OF ADRENOMEDULLIN ON THE BRONCHOPROTECTIVE EFFECTS OF THEOPHYLLINE

The guinea pigs were injected with theophylline $(20 \mathrm{mg} / \mathrm{kg}, 40 \mathrm{mg} / \mathrm{kg}, 60 \mathrm{mg} / \mathrm{kg}$ i.p.) or saline. Ten minutes after theophylline they were exposed to adrenomedullin $\left(10^{-10} \mathrm{M}, 30\right.$ breaths $)$ followed by histamine $\left(10^{-3} \mathrm{M}, 20\right.$ breaths) five minutes later. The percentage maximal inhibitory effects of theophylline were calculated.

\section{DRUGS}

Histamine, isoprenaline, and theophylline were obtained from the Sigma Chemical Company (St Louis, Missouri, USA) and human adrenomedullin and VIP were purchased from the Peptide Institute Inc (Japan). Stock solutions of histamine, adrenomedullin, VIP, isoprenaline, and theophylline were prepared in distilled water. All stock solutions were stored at $-70^{\circ} \mathrm{C}$ and dilutions from stock were all prepared fresh daily in $0.9 \% \mathrm{NaCl}$ to the final concentrations.

\section{DATA ANALYSIS}

Values are expressed as mean (SE). Statistical analysis was performed by one way analysis of variance followed by the Fisher test, and a $p$ value of less than 0.05 was considered significant.

\section{Results}

Baseline pulmonary resistance after aerosolised control solvent $\left(0.16(0.02) \mathrm{cm} \mathrm{H}_{2} \mathrm{O} / \mathrm{ml} / \mathrm{s}\right)$ was no different from that observed in control animals $\left(0.15(0.01) \mathrm{cm} \mathrm{H} \mathrm{H}_{2} \mathrm{O} / \mathrm{ml} / \mathrm{s}\right)$ and it had no effect on histamine-induced bronchoconstriction. Adrenomedullin $\left(10^{-9} \mathrm{M}\right)$ significantly inhibited histamine-induced bronchoconstriction but in a concentration of $10^{-10} \mathrm{M}$ it did not exhibit a bronchoprotective effect against histamine (fig 1).

Inhaled VIP $\left(10^{-9} \mathrm{M}\right)$ did not affect histamine-induced bronchoconstriction but markedly inhibited histamine-induced bronchoconstriction in the presence of adrenomedullin $\left(10^{-10} \mathrm{M}\right.$ ) (highest maximal inhibition 50 (15)\%; fig 2). Higher doses of VIP $\left(10^{-6} \mathrm{M}\right)$

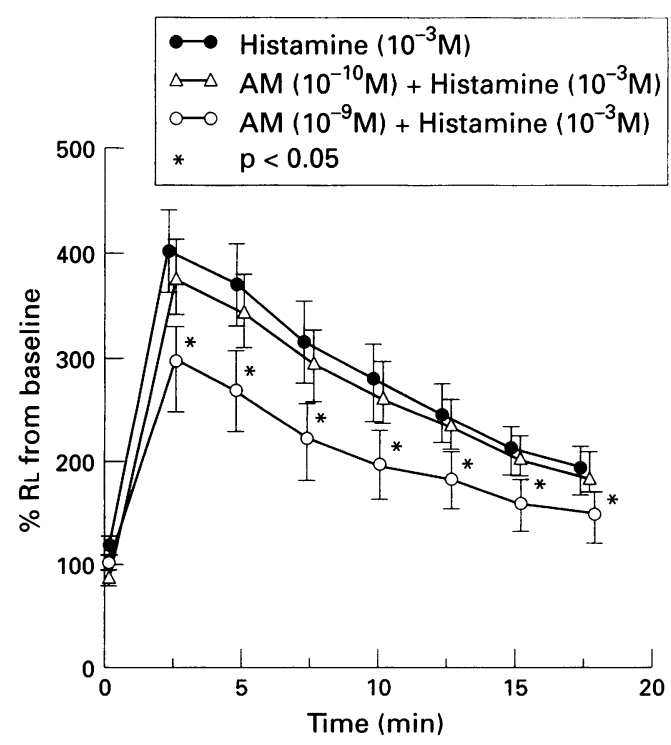

Figure 1 Inhibitory effect of adrenomedullin ( $A M)$ on histamine-induced bronchoconstriction (pulmonary resistance, $R \mathrm{~L}$ ). Each point represents the mean (SE) for five guinea pigs. ${ }^{*} p<0.05$ compared with values for histamine $\left(10^{-3} \mathrm{M}\right)$ alone. 


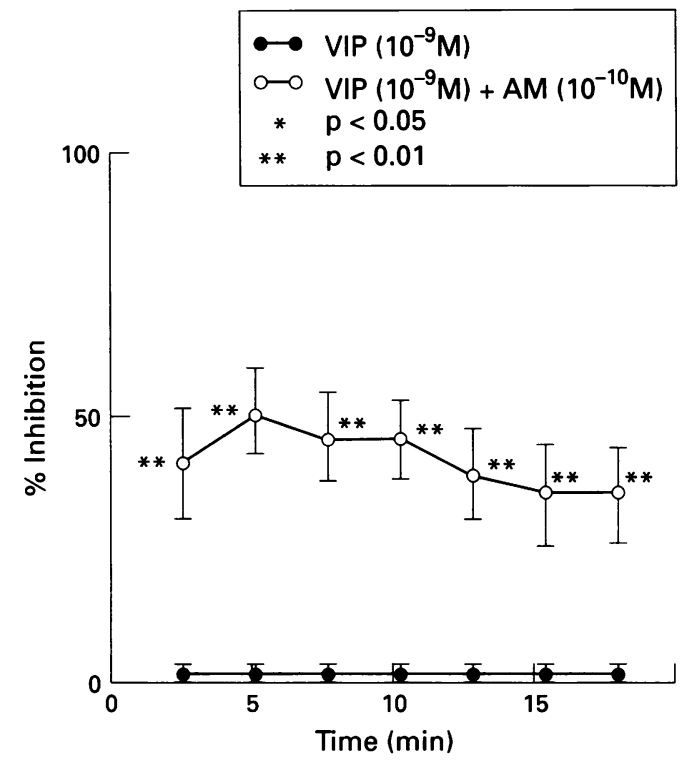

Figure 2 Inhibitory effect of vasoactive intestinal peptide (VIP, $\left.10^{-9} \mathrm{M}\right)$ on histamine-induced bronchoconstriction with (O) or without (O) adrenomedullin ( $A M$,

$\left.10^{-10} \mathrm{M}\right)$. Each point represents the mean (SE) for five guinea pigs. ${ }^{*} p<0.05, * * p<0.01$ compared with values for $\operatorname{VIP}\left(10^{-9} \mathrm{M}\right)$ alone.

significantly inhibited histamine-induced bronchoconstriction (highest maximal inhibition $54(12) \%$ ) but this effect was short lived. Adrenomedullin $\left(10^{-10} \mathrm{M}\right)$ also potentiated bronchoprotection induced by VIP $\left(10^{-6} \mathrm{M}\right)$ and prolonged it (highest maximal inhibition 75 (8)\%; fig 3). The $\beta$ adrenergic agonist isoprenaline $\left(10^{-8} \mathrm{M}\right)$ also significantly inhibited histamine-induced bronchoconstriction (highest maximal inhibition $43(12) \%$ ) and this effect was enhanced in the presence of adrenomedullin $\left(10^{-10} \mathrm{M}\right)$ (highest maximal inhibition 76 (11)\%; fig 4). Similarly, the nonselective phosphodiesterase inhibitor theo-

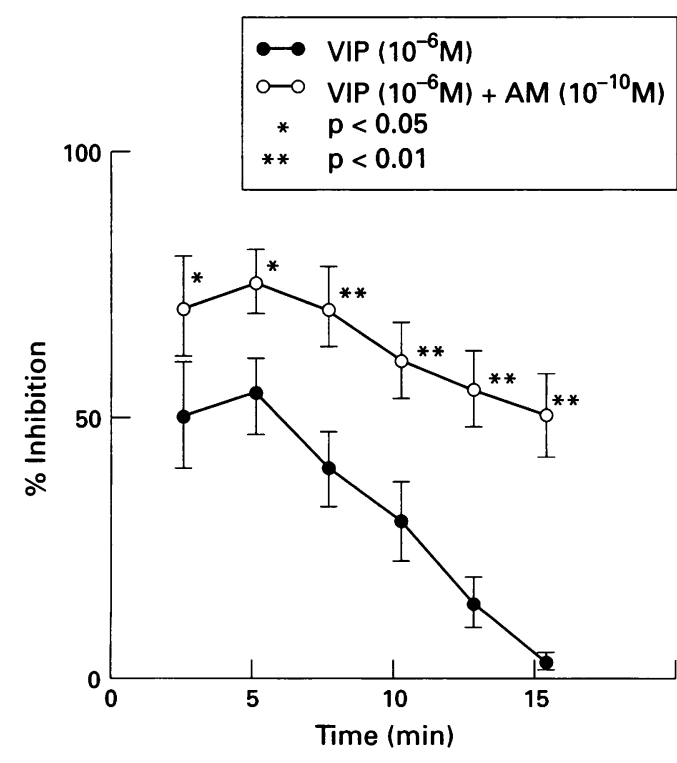

Figure 3 Inhibitory effect of vasoactive intestinal peptide (VIP, $\left.10^{-6} \mathrm{M}\right)$ on histamine-induced bronchoconstriction with $(\mathrm{O})$ or without (O) adrenomedullin (AM,

$\left.10^{-10} M\right)$. Each point represents the mean (SE) for five guinea pigs. ${ }^{*} p<0.05,{ }^{* *} p<0.01$ compared with values for VIP $\left(10^{-6} \mathrm{M}\right)$ alone.

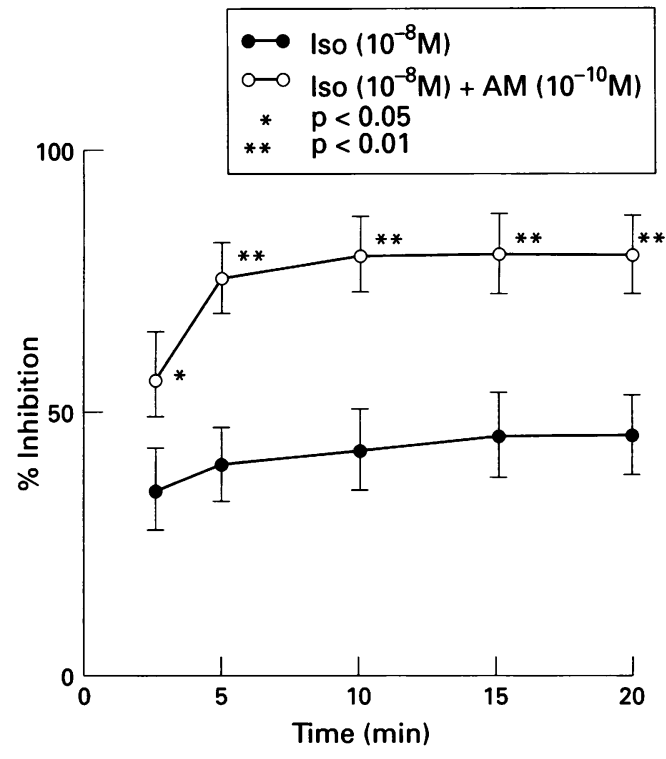

Figure 4 Inhibitory effect of isoprenaline $\left(10^{-8} \mathrm{M}\right)$ on histamine-induced bronchoconstriction with $(\mathrm{O})$ or without (O) adrenomedullin $\left(A M, 10^{-10} M\right)$. Each point represents the mean (SE) for five guinea pigs. ${ }^{*} p<0.05$, $* * p<0.01$ compared with values for isoprenaline $\left(10^{-8} \mathrm{M}\right)$ alone.

phylline in doses of $40 \mathrm{mg} / \mathrm{kg}$ and $60 \mathrm{mg} / \mathrm{kg}$ i.p. inhibited histamine-induced bronchoconstriction in a dose-dependent manner, but this bronchoprotective effect against histamine did not occur with a dose of $20 \mathrm{mg} / \mathrm{kg}$ i.p. Adrenomedullin $\left(10^{-10} \mathrm{M}\right)$ significantly potentiated theophylline-induced bronchoprotection, and the sub-bronchoprotective dose of $20 \mathrm{mg} / \mathrm{kg}$ was effective in preventing histamineinduced bronchoconstriction in the presence of adrenomedullin $\left(10^{-10} \mathrm{M}\right)$ (table 1$)$.

Aerosolised administration of adrenomedullin $\left(10^{-10} \mathrm{M}\right.$ or $\left.10^{-9} \mathrm{M}\right)$ and the combination of adrenomedullin and VIP or isoprenaline did not induce significant cardiovascular effects. In combination with theophylline $(40 \mathrm{mg} / \mathrm{kg}$ or $60 \mathrm{mg} / \mathrm{kg}$ ) adrenomedullin caused significant tachycardia, although at the lower dose of $20 \mathrm{mg} / \mathrm{kg}$ cardiovascular effects were not observed.

\section{Discussion}

We have found that adrenomedullin significantly potentiates and prolongs VIPinduced bronchoprotection. Intravenously administered VIP induces bronchodilatation in cats in vivo, ${ }^{10}$ and inhaled VIP protects against

Table 1 Synergistic effects of adrenomedullin on theophylline-induced bronchoprotection against histamine

\begin{tabular}{lc}
\hline & $\begin{array}{l}\text { Highest maximal } \\
\text { inhibition }(\%)\end{array}$ \\
\hline Theophylline $(20 \mathrm{mg} / \mathrm{kg})$ & $4(3)$ \\
Theophylline $(40 \mathrm{mg} / \mathrm{kg})$ & $22(12)$ \\
Theophylline $(60 \mathrm{mg} / \mathrm{kg})$ & $50(8)$ \\
Adrenomedullin $\left(10^{-10} \mathrm{M}\right)$ & \\
+ Theophylline $(20 \mathrm{mg} / \mathrm{kg})$ & $25(8)^{* *}$ \\
+ Theophylline $(40 \mathrm{mg} / \mathrm{kg})$ & $48(13)^{* *} \dagger$ \\
+ Theophylline $(60 \mathrm{mg} / \mathrm{kg})$ & $80(12)^{* *} \ddagger$ \\
\hline
\end{tabular}

${ }^{* *} \mathrm{p}<0.01$ compared with theophylline alone.

$\dagger \mathrm{p}<0.05 ; \neq \mathrm{p}<0.01$ compared with adrenomedullin + $\dagger \mathrm{p}<0.05 ; \neq p<0.01 \mathrm{com}$.
theophylline $(20 \mathrm{mg} / \mathrm{kg})$.

Each group represents the mean (SE) for six guinea pigs. 
the bronchoconstrictor effects of histamine and prostaglandin $F_{2}$ in dogs. ${ }^{11}$ In asthmatic patients, however, inhaled VIP had no bronchodilator effect although $\beta_{2}$ adrenergic agonists were markedly effective in the same subjects. ${ }^{12}$ Inhaled VIP has only a small protective effect against histamine ${ }^{13}$ and has no effect against exercise-induced bronchoconstriction. ${ }^{14}$ The lack of potency of inhaled VIP may be explained by limitation of diffusion of VIP across the airway epithelium to reach receptors in the airway smooth muscle or by enzymatic degradation of VIP. We suggest that adrenomedullin might potentiate VIP receptor agonist-induced bronchoprotection, since recently designed VIP analogues were found not to be susceptible to peptidases and to have a high metabolic stability. ${ }^{15}$

The precise mechanism responsible for the synergism in the bronchoprotective effects of adrenomedullin and VIP or isoprenaline is unclear. Adrenomedullin induces vasodilation by increasing cAMP levels in vascular smooth muscle cells which possess adrenomedullin receptors functionally coupled to adenylate cyclase. ${ }^{16}$ cAMP is thought to have an important role as an intracellular mediator in the regulation of airway functions. We have speculated that binding sites for adrenomedullin are also present on guinea pig airway smooth muscle $^{4}$ and that their stimulation by adrenomedullin may increase cAMP levels. Both VIP and isoprenaline can also directly stimulate the production of cAMP in airway smooth muscle cells and may consequently have bronchodilator effects. Adrenomedullin and VIP or isoprenaline might display synergistic effects in the formation of cAMP in airway smooth muscles, where cAMP levels are drastically increased, and activate those intracellular mechanisms that are regulated by cAMP-dependent phosphorylation. ${ }^{17}$

In vitro studies have established that phosphodiesterase (PDE) inhibitors effectively relax precontracted airway smooth muscle preparations of guinea pig and human origin. ${ }^{18}$ They are therefore considered a principal molecular target for novel anti-asthmatic agents. The PDEs are a family of enzymes which hydrolyse the $3^{\prime}$-ribose phosphate bond of the naturally occurring second messenger nucleotide, cAMP, and cGMP (cyclic guanosine monophosphate) to form biologically inactive 5'-nucleoside monophosphates. Adrenomedullin and the non-selective PDE inhibitor, theophylline, might therefore increase the level of cAMP in airway smooth muscle cells in a complementary manner. A recent study found that low sub-bronchodilating doses of theophylline (up to $25 \mathrm{mg} / \mathrm{kg}$ i.p.) did not reduce histamine-induced bronchoconstriction. ${ }^{19}$ However, our findings suggest that a subthreshold concentration of adrenomedullin $\left(10^{-10} \mathrm{M}\right)$ significantly potentiates the bronchoprotective effects of low doses of theophylline $(20 \mathrm{mg} / \mathrm{kg}$ i.p.) against histamine.

We have noted adverse effects with the use of these bronchodilators including tachycardia.
Interestingly, intravenous administration of adrenomedullin did not cause reflex tachycardia despite a marked reduction in mean blood pressure in anaesthetised rats. ${ }^{20}$ We therefore consider that $\beta_{2}$ agonist-induced tachycardia would not be enhanced when $\beta_{2}$ agonists are given in combination with adrenomedullin.

In conclusion, this study has shown that adrenomedullin potentiates the bronchoprotective effects of different classes of bronchodilators in anaesthetised guinea pigs. It is particularly interesting as it suggests that administration of a subthreshold concentration of adrenomedullin may cause synergistic interactions with other airway relaxants to promote bronchodilatation.

The authors thank Ms Yuriko Takahashi for secretarial assistance in preparation of the manuscript.

1 Kitamura K, Kangawa K, Kawamoto M, Ichiki Y, Nakamura S, Matsuo H, Eto T. Adrenomedullin: a novel hypotensive peptide isolated from human pheochromocytoma. Biochem Biophys Res Commun 1993;192:553-60

2 Kitamura K, Kangawa K, Kojima M, Ichiki Y, Matsuo $\mathrm{H}$, Eto $\mathrm{T}$. Complete amino acid sequence of porcine adrenomedullin and cloning of $\mathrm{CDNA}$ encoding its preadrenomedullin and cloning of cDNA

3 Martinez A, Miller MJ, Unsworth EJ, Siegfried JM, Cuttitta F. Expression of adrenomedullin in normal human lung and in pulmonary tumors. Endocrinology 1995;136:4099 105 .

4 Kanazawa H, Kurihara N, Hirata K, Kudoh S, Kawaguchi $T$, Takeda $T$. Adrenomedullin, a newly discovered hypotensive peptide, is a potent bronchodilator. Biochem Biophys Res Commun 1994;205:251-4.

5 Polak JM, Bloom SR. Regulatory peptides of the gastrointestinal and respiratory tracts. Arch Int Pharmacodyn 1986;280:16-49.

6 Dey RD, Shannon WA, Said SI. Localization of VIP immunoreceptor nerves in airways and pulmonary vessels of dogs, cats and human subjects. Cell Tissue Res 1981;220: dogs, cats

7 Palmer JB, Cuss FMC, Barnes PJ. VIP and PHM and their role in non-adrenergic inhibitory responses in isolated role in non-adrenergic inhibitory responses in
human airways. $\mathcal{F}$ Appl Physiol 1986;61:1322-8.

8 Torphy TJ, Undem BJ, Cieslinski LB, Luttmann MA Reeves ML, Hay DWP. Identification, characterization and functional role of phosphodiesterase isozymes in human airway smooth muscle. F Pharmacol Exp Ther 1993 265:1213-33.

9 Dusser DJ, Umeno E, Graf PD, Djokic TD, Borson DB Nadel JA. Airway neutral endopeptidase-like enzyme modulates tachykinin-induced bronchoconstriction in vivo. $f$ Appl Physiol 1988;65:2585-91.

10 Diamond L, Szarek JL, Gillespie MN, Altiere RJ. In vivo bronchodilatory activity of vasoactive intestinal peptide in the cats. Am Rev Respir Dis 1983;128:827-32

11 Said SI, Geumi A, Hara N. Bronchodilator effect of VIP in vivo: protection against bronchoconstriction induced by histamine and
prostaglandin F2. New York: Raven Press, 1982: 185-91.

12 Barnes PJ, Dixon CMS. The effect of inhaled vasoactive intestinal peptide on bronchial reactivity to histamine in man. Am Rev Respir Dis 1984;130:162-6.

13 Palmer JBD, Cuss FMC, Warren JB, Barnes PJ. The effect of infused vasoactive intestinal peptide on airway function in normal subjects. Thorax 1986;41:663-6.

14 Bungaad A, Enehjelm SD, Aggestrop S. Pretreatment of exercise-induced asthma with inhaled vasoactive intestinal peptide. Eur f Respir Dis 1983;64:427-9.

15 O'Donnell M, Garippa RJ, Rinaldi N, Selig WM, Smiko B Renzetti L, et al. Ro25-1553: a novel long-acting vasoactive intestinal peptide agonist. Part 1: In vitro and in vivo bronchodilator studies. F Pharmacol Exp Ther 1994;270 1282-8.

16 Eguchi S, Hirata Y, Kano H, Sato K, Watanabe Y, Watanabe TX, et al. Specific receptors for adrenomedullin in cultured rat vascular smooth muscle cells. FEBS Lett 1994;340 $226-30$.

17 Torphy TJ, Burman M, Huang LBF, Tucker SS. Inhibition of the low $\mathrm{Km}$ cyclic AMP phosphodiesterase in intact trachealis by SKF 94836: mechanical and biochemical trachealis by SKF 94836: mechanical and bioch.

18 De Boer J, Philpott AJ, Van Amsterdam RGM, Shahid $M$, Zaagsma J, Nicholson CD. Human bronchial cyclic nucleotide phosphodiesterase isozymes: biochemical and nucleotide phosphodiesterase isozymes: biochemical and
pharmacological analysis using selective inhibitors. $\mathrm{Br} \mathfrak{f}$ Pharmacological analysis using

19 Santing RE, Olymulder CG, Van der Molen K, Meurs H Zaagsma J. Phosphodiesterase inhibitors reduce bronchial Zaagsma J. Phosphodiesterase inhibitors reduce bronchial hyperreactivity and airway inflammation in un

20 Ishiyama Y, Kitamura K, Ichiki Y, Nakamura S, Kida O Kangawa $\mathrm{K}$, et al. Hemodynamic effects of a novel hypotensive peptide, human adrenomedullin, in rats. Eur $\mathcal{F}$
Pharmacol 1993;241:271-3. 